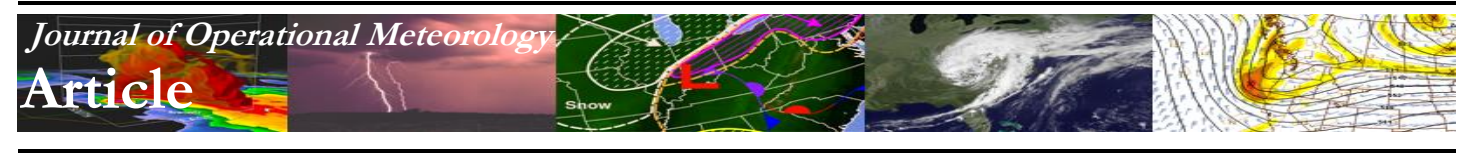

\title{
Operational Recognition of High Precipitation Efficiency and Low-Echo-Centroid Convection
}

\author{
JEFFREY D. VITALE \\ National Weather Service Forecast Office, Lubbock, Texas \\ TED RYAN \\ National Weather Service Forecast Office, Fort Worth, Texas \\ (Manuscript received 3 April 2012; in final form 27 September 2012)
}

\begin{abstract}
A rarely studied cause of flash flooding - the leading cause of weather-related fatalities in the United States-is from a type of convective cell called a low-echo centroid (LEC), where most of the reflectivity is within the warm portion of the cloud-bearing layer. Since the inception of the LEC classification, the definition has remained ambiguous and difficult to quantify. Operational identification of LEC convection is critical to anticipating flash flooding, because rainfall estimates from the Weather Surveillance Radar-1988 Doppler often are too low. Four LEC convective cases are examined in order to refine the definition and to provide the characteristic features of these storms. From the sample events, two types of LEC storms were identified that shared features that would assist in their operational identification. Analyses indicated that radar reflectivity $\leq 60 \mathrm{dBZ}$ should exist within the cell, the cell should possess a long-lived steady-state reflectivity of 45-55 dBZ, and the LEC cell should have increasing reflectivity as height decreases. The development of a system to assist operational forecasters in identification of the atmospheric parameters favoring LEC convection, and the real-time recognition of LEC events to support flash-flood-warning decision making, is an important effort to reducing unwarned and/or unexpected flooding events.
\end{abstract}

\section{Introduction}

Over the last few decades, flash flooding has ranked as the leading cause of fatalities associated with non-tropical convection in the United States (NOAA 2010). Anticipating a flash-flood event is different than forecasting the occurrence of other convective hazards such as tornadoes or large hail because it requires several non-meteorological factors to be present with excessive rainfall rates. Excessive rainfall can be defined operationally as a rainfall rate exceeding flash-flood guidance. These nonmeteorological factors include antecedent soil moisture, drainage basin characteristics, and the interaction of runoff with civil infrastructure. Nonmeteorological factors often are unknown or approximated, but errors in estimation of the primary meteorological factor-precipitation rates-also can occur. Overestimated rainfall intensity can result in flash-flood warnings issued for events that do not occur (i.e., a false alarm). In contrast, underestimated rainfall intensity can increase the chance for missed events - a flash-flood event occurring with no warning. National flash-flood warning statistics from fiscal year 2011 (October 2010 to September 2011) show a probability of detection of $79 \%$, false alarm ratio of $49 \%$, and an average lead time of $73 \mathrm{~min}$ (NOAA 2011). Unwarned flash-flood events are especially counter to the core mission of the National Weather Service (NWS) to protect life and property. Missed events contribute toward a lack of response and may lead to fatalities or property damage that otherwise could have been prevented or mitigated.

The deployment of the Weather Surveillance Radar-1988 Doppler (WSR-88D) radar network across the United States in the 1990s has contributed to substantial improvements in the ability to forecast flash floods (Polger et al. 1994). This occurred because the WSR-88D produces real-time rainfall 
estimates from computer algorithms that associate reflectivity values with observed precipitation rates. A forecaster's use of rainfall estimates in conjunction with short-term convective trends is often sufficient to anticipate a flash-flood event. However, this method places heavy reliance upon the WSR-88D precipitation-estimation algorithms, which unfortunately can be inaccurate for a number of reasons (Baeck and Smith 1998) - including its inability to accurately depict precipitation estimates with different storm types. One specific storm type, called a low-echo centroid (LEC), where most of the reflectivity is within the warm portion of the cloud-bearing layer, can be especially problematic for precipitationestimation algorithms.

This research focused on LEC convective storms in the central and southern United States to help identify and characterize the specific meteorological causes that resulted in radar rainfall-rate underestimation. This systematic underestimation results from cloud microphysical properties typically associated with convection over continental locations in tropical and semi-tropical airmass environments when the convective rainfall estimation algorithm is in effect. An examination of several flash-flood events over the south-central United States has identified common characteristics associated with LEC convection. These are used to demonstrate how an operational forecaster, using a more complete definition and more comprehensive understanding of an LEC storm, may improve LEC recognition in a real-time operational setting.

\section{Background}

\section{a. Radar fundamentals}

For any given precipitation-producing system, cloud microphysics are responsible for significant variations in the accuracy of radar-based precipitation estimation because of sampling and assumptions related to radar-echo returns. Radar-based precipitation estimates utilize reflectivity to derive precipitation rate in a scanned volume. Reflectivity perceived by the radar $(Z)$ varies by the 6th power of the average diameter of the rain droplets $\left(D^{6}\right)$, the square of the dielectric constant of the targets $\left(|K|^{2}\right)$, and the size distribution of the drops $\left(N_{o} e^{-\Lambda D}\right)$ as given by Doviak and Zrnić (1993):

$$
Z=\int_{0}^{D_{\max }} N_{o} e^{-\Lambda D} D^{6} d D
$$

where $D_{\max }$ is the maximum drop diameter, $N_{o}$ is the concentration parameter, and $\Lambda$ is the distribution slope factor. Precipitation rate $(R)$, on the other hand, is dependent on $N_{o} e^{-\Lambda D}$, hydrometer volume, and hydrometeor fall velocity $[v(D)]$, as shown by:

$R=\int_{0}^{D_{\max }} N_{o} e^{-\Lambda D}\left(\frac{\pi D^{3}}{6}\right) v(D) d D$.

Thus, $Z$ and $R$ have similar functions and are related as

$Z=a R^{b}$

where $a$ and $b$ are coefficients that depend on the type of precipitation, which can have different $\Lambda,|K|^{2}, N_{o}$, and $v$ (Brandes et al. 2006).

Equation (3) (specifically the constants $a$ and $b$ ) is commonly referred to as the $Z-R$ relationship. Several values for $a$ and $b$ have been derived for precipitation estimation in different atmospheric regimes (Wilson and Brandes 1979; Rosenfield et al. 1993). Using a suitable $Z-R$ relationship can result in reasonably accurate estimates. However, these $Z-R$ relationships are applied to the entire radar domain, and if precipitation resulting from different microphysical processes is occurring in different locations, significant errors may arise owing to different dropsize distributions (DSDs) and phase changes.

A simple example that illustrates the fundamental problem with using radar reflectivity to estimate rainfall rates can be shown by solving these three equations for two different DSDs. Equation (1) states that $Z$ is proportional to the sixth power of the drop diameter, indicating that drop size, rather than number of drops in the sampled volume, is the heaviest weight in the calculation. For example, solving Eq. (1) for 729 1 -mm diameter drops per cubic meter will yield a $Z$ of $29 \mathrm{dBZ}$, as will a single $3-\mathrm{mm}$ diameter drop in one cubic meter. If a size-appropriate fall velocity is used (Löffler-Mang and Joss 2000), the rainfall rate given by Eq. (2) for the 729-drop example is $5.6 \mathrm{~mm} \mathrm{~h}^{-1}$

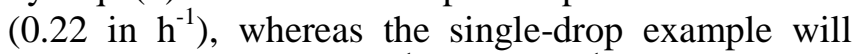
only produce $0.25 \mathrm{~mm} \mathrm{~h}^{-1}\left(0.01 \mathrm{in} \mathrm{h}^{-1}\right)$ (WDTB 2012, 329-335). An algorithm that uses a single $Z-R$ relationship to estimate precipitation across the entire radar domain uses reflectivity values only-as estimated from backscattered energy-to derive a rainfall rate from Eq. (3). If both DSD examples were present in different storms across a single radarcoverage area, no single $Z-R$ relationship could be 
used to accurately estimate rainfall rates for both storms. This example shows rather dramatically why many different rainfall-rate values are possible for a given reflectivity value if there are non-homogeneous DSDs within the radar domain.

\section{b. Precipitation-production processes}

In the real atmosphere, different DSDs are generated as a result of differing precipitationproduction mechanisms (Marshall and Palmer 1948; Srivastava 1971; Yuter and Houze 1997; Bringi et al. 2003). Precipitation typically forms from collisioncoalescence (commonly referred to as a warm-rain or warm-cloud process), the Bergeron process (which involves water in the ice phase), or a combination of the two. Convection that relies upon collisioncoalescence to generate rainfall usually is more efficient at converting available cloud water into precipitation than the Bergeron process (Lamb 2001).

The collision-coalescence or warm-cloud method occurs in the absence of water in the ice phase and is very common at tropical latitudes where the melting level often is $>4 \mathrm{~km}$ above mean sea level (Battan and Braham 1956). In this process, cloud droplets suspended in the air interact with each other, either by colliding and bouncing off each other or by combining to form a larger droplet. The Bergeron process involves both ice nuclei and supercooled water droplets and comparatively is a faster but less efficient way to generate precipitation-sized particles. This process generally begins at temperatures below $-10^{\circ} \mathrm{C}$ when naturally occurring ice nuclei activate and allow ice crystals to form inside a cloud (Wallace and Hobbs 1977).

There is a natural tendency for DSDs produced by warm-cloud processes to consist of a large number of small-diameter drops (Squires 1956). Precipitation from the Bergeron process has a DSD skewed toward a small number of large-diameter drops. Although the radar-reflectivity signal may be identical for either case, the large number of small drops will produce more rainfall (Ulbrich and Atlas 2008). Therefore, knowing the mechanism that is producing precipitation allows for better $Z-R$ approximations. In the absence of using a dual-polarization radar to sample the mean drop size, the best way to determine the precipitation mechanism is to anticipate when the atmosphere will be favorable for warm-cloud convection.

Identifying the atmospheric conditions that are favorable for convection where collision-coalescence can be the dominant rainfall-producing mechanism is the first step toward recognizing the resulting convective signatures in real-time. Diagnosing the presence of ingredients that allow for excessive rainfall rates has been an effective flash-flood forecast tool (Doswell et al. 1996). Similarly, an ingredientsbased checklist of the atmospheric conditions required for warm-cloud convection for use in conjunction with numerical model guidance would be a valuable way to anticipate this type of convection. Many of the ingredients required for warm-cloud convection are similar to those needed to produce excessive rainfall rates.

Excessive rainfall events produced from collisioncoalescence processes require

- a deep warm-cloud layer,

- weak and/or shallow updrafts,

- limited cloud-layer wind shear, and

- high relative humidity through a deep layer (Davis 2001).

Warm-cloud depth (WCD), defined here as the layer from the lifted condensation level (LCL) to the $-10^{\circ} \mathrm{C}$ level, is the area of the cloud where collisioncoalescence can occur provided that all water remains in liquid phase. The melting level was not used for the top of the WCD calculation because cloud water remains in a supercooled phase without the presence of ice nuclei, which do not become activated until temperatures are colder than about $-10^{\circ} \mathrm{C}$ (WDTB 2011, 10-12). A shallow warm-cloud layer will limit the volume available for this process. In the case of a shallow warm-cloud layer, incoming cloud water vapor is more likely to be converted into ice in the subfreezing portions of the clouds where it is comparatively less efficient at reaching the ground as precipitation (Lamb 2001). Even though there is no minimum value of WCD, all of the excessive rainfall cases presented in section 3 of this investigation had WCD values $>4 \mathrm{~km}(13400 \mathrm{ft})$ as determined from viewing representative vertical temperature profiles.

The updraft characteristics are important for several reasons. Shallow updrafts, where the equilibrium level (EL) is below the $-10^{\circ} \mathrm{C}$ level, ensure that the Bergeron process will not occur. In situations where the $\mathrm{EL}$ is higher than the $-10^{\circ} \mathrm{C}$ level, the updraft must have slow vertical velocities through a deep warm-cloud layer. This is because collisioncoalescence is a relatively time-consuming process, 
and a weak updraft gives raindrops the time required to grow large enough to precipitate before the updraft adiabatically cools below $-10^{\circ} \mathrm{C}$. The updraft characteristics can be diagnosed by using either an observed or forecast sounding that is representative of the convective environment. A narrow or thin profile of convective available potential energy (CAPE, computed herein using the most-unstable parcel) on an observed or forecast sounding provides an indication of slow updraft velocities (Zipser and LeMone 1980). Tilting of an updraft owing to vertical wind shear can extrude embryonic hydrometeors outside of the saturated cloud where precipitation efficiency can be reduced because of evaporation (Schoenberg Ferrier et al. 1996).

Relative humidity, both below the cloud base and within the mid- and upper-levels of the atmosphere, is one of the most important variables used to assess the efficiency of convection in converting available cloud water into precipitation at the surface. This often is referred to as precipitation efficiency. The relative humidity below the base of the cloud/LCL determines the amount of sub-cloud evaporation that occurs. Similarly, a cloud naturally will entrain some quantity of environmental air (Doswell et al. 1996). Midlevel and sub-cloud evaporation can create negatively buoyant (i.e., cold) downdrafts, which severely hinder the ability of warm-cloud convection to produce excessive rainfall. This is because convection cannot be sustained in the presence of cold downdrafts unless the cell has adequate motion, or if vertical wind shear is present. As already noted, vertical wind shear is detrimental to weak updrafts that are required for warm-rain convection. If cell motion is significant, the effect is to limit the site-specific duration of heavy rainfall.

\section{c. The low-echo centroid}

Many studies of excessive rainfall events often describe convection as having an LEC (Caracena et al. 1979; Smith et al. 1996; Baeck and Smith 1998). LEC is the term used to describe the vertical structure evident on a radar cross section of a cell where the centroid (i.e., highest reflectivity) of the cell is located in the lower sections of the cloud-places that typically are $>0{ }^{\circ} \mathrm{C}$. Unfortunately, the definition of an LEC cell has remained vague since the term was first coined by Caracena et al. (1979) when it was used to describe the radar characteristics of the cell responsible for the Big Thompson Canyon flood of 1976.
The reason why a mature warm-cloud cell will have this "bottom heavy" reflectivity structure can be explained by exploring raindrop development via collision-coalescence. Raindrop growth in collisioncoalescence tends to occur as the more massive droplets intersect, and collect, smaller droplets on their descent through the updraft. Therefore, the largestdiameter raindrops will be found at the bottom of the cell, with the more embryonic raindrops located at progressively higher altitudes. The radar-reflectivity Eq. (1) states that these larger droplets will reflect considerably more signal back to the radar, thus resulting in higher reflectivity values.

Although the LEC definition is vague, it does address the fundamental radar signature that is associated with convection where the collisioncoalescence process is responsible for the majority of the precipitation production. However, the presence of higher reflectivity in the lower portions of a cell does not necessarily mean the collision-coalescence process is the cause. For instance, a radar scan of a cell with a descending hail core, or during a late phase of a precipitation cycle, also may have an LEC appearance. Therefore, additional (but rudimentary) guidelines on the definition of LEC signatures were informally proposed. NWS radar-training material suggests the height of the 30-dBZ echo should remain below the environmental melting level (WDTB 2012, 329-335). Another informal rule suggests that tracking the height of the 50-dBZ echo and ensuring it remains below the melting level throughout a cell's lifetime helps identify an LEC cell. However, these methods offer no aid in distinguishing between a cell that is steady-state and precipitating as a result of collision-coalescence, or a cell that merely is weak or decaying in which precipitation formed from utilizing ice and supercooled water.

Case studies where the LEC structure and warmrain process have been identified also noted a low number of cloud-to-ground (CG) lightning strikes (Petersen et al. 1999; Bruning et al. 2007). This can be attributed to a lack of both graupel and large vertical velocities from strong updrafts within a convective cell. These two characteristics are the fundamental ingredients that lead toward charge separation and lightning discharge (Lucas et al. 1994; Zipser and Lutz 1994).

Inasmuch as these guidelines can help, the LEC signature remains ill-defined, difficult to recognize, and easy to overlook, especially in the presence of 
continental convection with a high-echo centroid (HEC) ${ }^{1}$. The inability to identify the LEC structure in real-time has resulted in the occurrence of unwarned flash-flood events during the last couple of decades (Davis 2004).

One such example of a well-documented LEC storm that produced flash flooding occurred on 28 July 1997 in Fort Collins, Colorado. The flash flooding occurred when over $250 \mathrm{~mm}$ (10 in) of rain fell in less than a 6-h period. This storm caused over $\$ 200$ million in damage and resulted in five fatalities (Kelsch 1998; Petersen et al. 1999). Low-level upslope flow from the east increased the low-level moisture content and helped lift the air. The moisture was present through a deep layer of the atmosphere. In addition, weak shear profiles, warm-topped clouds on satellite images, the lack of hail reports, and limited amounts of lightning provide evidence that the warm-rain process was dominant. A proximity sounding from Denver, Colorado, at 0000 UTC 29 July 1997 showed the following characteristics:

- relatively small CAPE of $868 \mathrm{~J} \mathrm{~kg}^{-1}$;

- moderate lifted index of $-2.8 \mathrm{C}^{\circ}$;

- high melting level of $3.3 \mathrm{~km}$ above ground level (AGL);

- large surface-500-hPa precipitable water (PW) of $33 \mathrm{~mm}$ (1.3 in), which is about $179 \%$ of normal;

- LCL at $764 \mathrm{hPa}$ (855 m AGL), with a level of free convection at $690 \mathrm{hPa}$, and a surface pressure of $843 \mathrm{hPa}$;

- light-to-moderate mid-tropospheric winds of 5-10 $\mathrm{m} \mathrm{s}^{-1}(10-20 \mathrm{kt})$ from the southwest; and

- minimal CG lightning (0.5 flashes $\left.\min ^{-1}\right)$ (Kelsch 1998; Petersen et al. 1999).

The warm-rain process was further identified and verified through the use of a dual-polarization radar at Colorado State University; the reader is referred to Petersen et al. (1999) for additional discussion on this case.

\footnotetext{
1 The term high-echo centroid (HEC) was developed within this study for brevity, and to our knowledge this term has not been used previously in the refereed literature. An HEC storm (compared to an LEC storm) has its largest reflectivity values above the melting level.
}

\section{Case analyses}

a. Kansas Turnpike (30 August 2003)

\section{1) OVERVIEW}

On the evening of 30 August 2003, an isolated LEC cell developed over Interstate-35 (Kansas Turnpike) near Emporia, Kansas. The cell moved very slowly and persisted for $<3 \mathrm{~h}$ but inundated Jacob Creek with 150-200 mm (6-8 in) of rain between 2300-0200 UTC. Jacob Creek greatly exceeded the capacity of the culvert underneath the interstate and surged onto the northeast-bound lanes. This flash flood resulted in six fatalities as water piled up against, and then washed away, the concrete barriers separating the two sides of the interstate. It was estimated that property damage of $\$ 250000$ was sustained from this flash flood (NCDC 2003).

\section{2) SOUNDING ANALYSIS}

A rapid update cycle (RUC-2) (Benjamin et al. 1998) model sounding at 1800 UTC 30 August 2003 (Fig. 1) was analyzed upwind from the cell location. This upwind sounding was located $110 \mathrm{~km}$ southsoutheast of the LEC cell's location, which was determined to be representative of the storm inflow based on the examination of the 850-300-hPa wind. The sounding indicated a small amount of CAPE with a value of $316 \mathrm{~J} \mathrm{~kg}^{-1}$. The shape of the CAPE also was

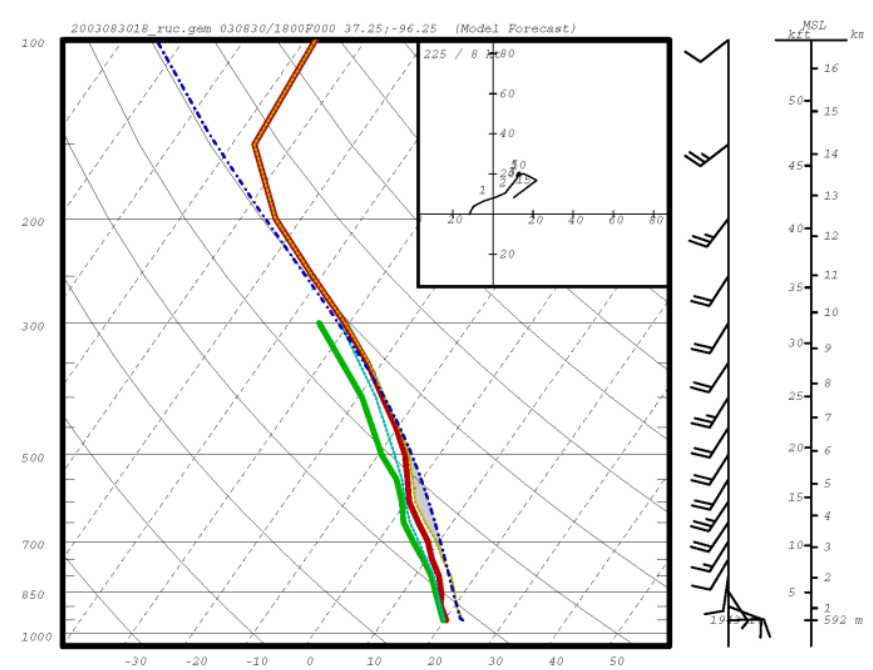

Figure 1. RUC-2 initialization sounding for 1800 UTC 30 August 2003, $110 \mathrm{~km}$ upwind of the Kansas turnpike LEC cell. The vertical scale on the left is in $\mathrm{hPa}$; the horizontal scale is in ${ }^{\circ} \mathrm{C}$; and wind is in kt. The red line is temperature while the green line is the dewpoint. The shaded portion represents positive CAPE. Click image for an external version; this applies to all figures hereafter. 
"tall and skinny," with the positive area (gray, Fig. 1) distributed over a 300-hPa depth of the sounding; but most of the CAPE was below the $-10^{\circ} \mathrm{C}$ isotherm. The EL was at a height of $300 \mathrm{hPa}$ while the tropopause was at a height of $150 \mathrm{hPa}$ (as determined by the temperature profile). Speed shear was weak with wind speeds within the WCD ranging between $5-10 \mathrm{~m} \mathrm{~s}^{-1}$ $(10-20 \mathrm{kt})$. Based on this sounding, the WCD was exceptionally large and approached $6.4 \mathrm{~km}(21900 \mathrm{ft})$. Also, the entire sounding was nearly saturated. The PW for this event was $48 \mathrm{~mm}$ (1.90 in), which was about $120 \%$ of normal.

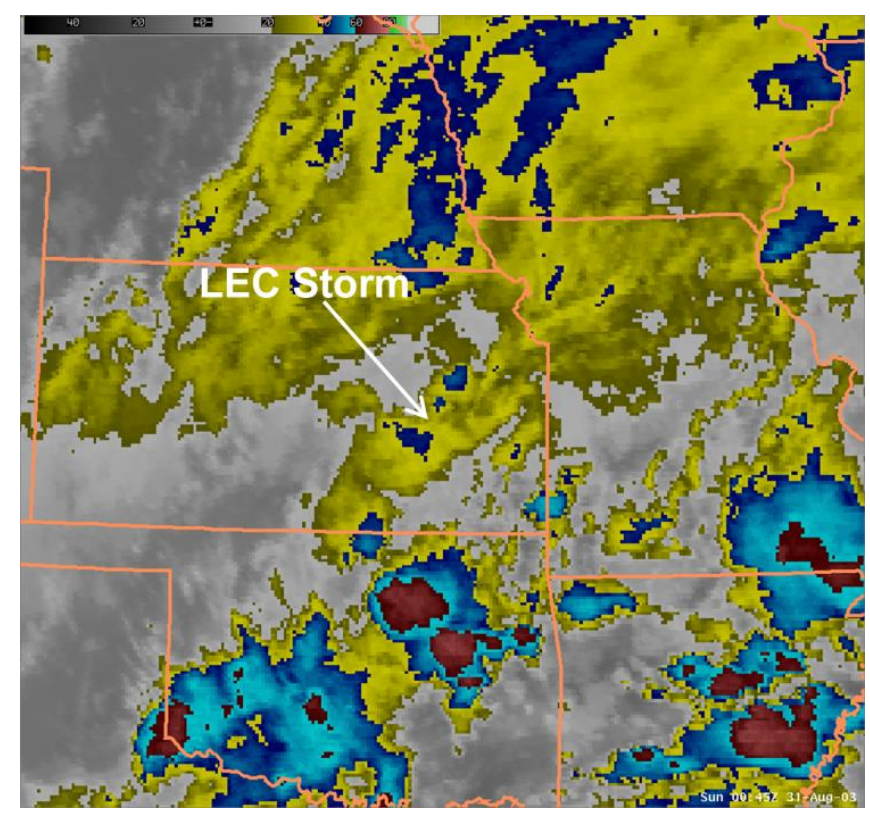

Figure 2. Enhanced GOES-IR satellite image for 0045 UTC 31 August 2003. The location of the LEC storm in Kansas is indicated by the white arrow. Temperature scale $\left({ }^{\circ} \mathrm{C}\right)$ is at the upper left.

\section{3) RADAR/SATELLITE ANALYSIS}

The storm cell formed about $19 \mathrm{~km}(12 \mathrm{mi})$ west of Emporia, Kansas, and reached peak intensity at 0035 UTC 31 August 2003. An examination of the Geostationary Operational Environmental Satellite (GOES) infrared (IR) satellite image at 0045 UTC 31 August 2003 (Fig. 2) indicated that the cell coincided with warm cloud-top temperatures between -30 and $-40^{\circ} \mathrm{C}$ near the time of peak intensity. These temperatures corresponded to pressures near $350 \mathrm{hPa}$, similar to the EL in the RUC-2 model sounding. To the south, in Oklahoma and Texas, there were colder cloud-top temperatures $\left(-60\right.$ to $\left.-80^{\circ} \mathrm{C}\right)$ associated with thunderstorms that produced high winds, copious lightning, and hail at the same time of the LEC cell to the north. Additionally, there were no reports of CG
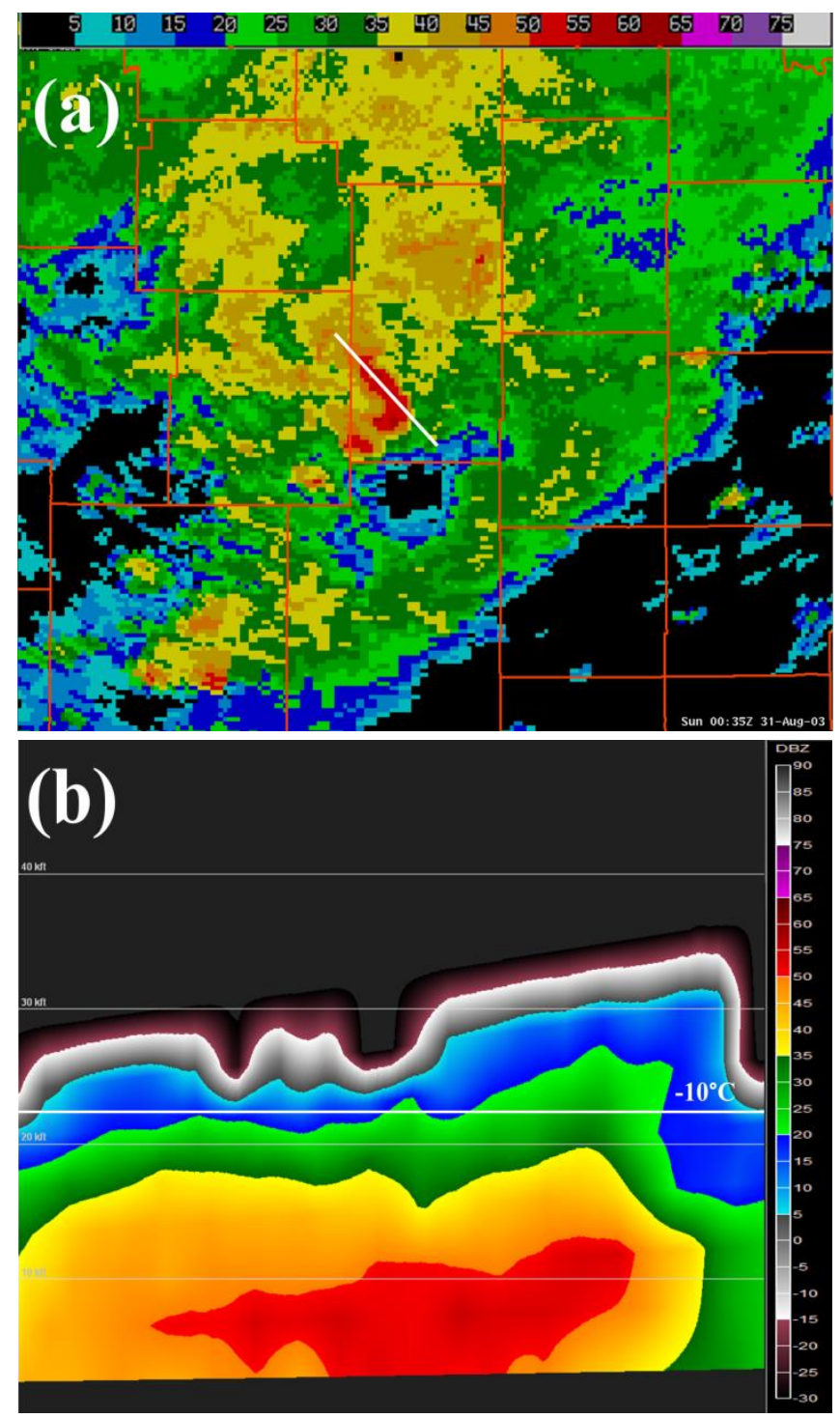

Figure 3. (a) Topeka, KS (KTWX), WSR-88D composite reflectivity at 0035 UTC 31 August 2003. The thick line through the LEC cell indicates the orientation of the cross section in (b). (b) KTWX reflectivity cross section (northwest-to-southeast) at 0035 UTC 31 August 2003. The thick horizontal white line indicates the $-10^{\circ} \mathrm{C}$ isotherm.

lightning throughout the lifetime of the LEC cell (Vitale et al. 2009).

At 0035 UTC 31 August 2003, reflectivity values were between 50-55 dBZ (Fig. 3a). The reflectivity cross section indicated by the thin, white line is shown in Fig. 3b. All reflectivity values were $<55 \mathrm{dBZ}$ and the highest values also were found below the $-10^{\circ} \mathrm{C}$ isotherm. Radar rainfall estimates had underestimated precipitation by a factor of 2-3 during this event using the local NWS default coefficients in Eq. (3) (i.e., $Z=300 R^{1.4}$ ). Peak vertically integrated liquid (VIL) values at the same time were around $25-30 \mathrm{~kg} \mathrm{~m}^{-2}$. 
This, combined with echo-top (ET) values between 10.7-12.2 km (35 000-40 $000 \mathrm{ft})$ AGL, provided VIL density values of $2.0 \mathrm{~kg} \mathrm{~m}^{-3}$. VIL density is defined as the quotient of VIL and ET.

\section{b. Dallas, Texas (19 March 2006)}

\section{1) OVERVIEW}

Widespread convection occurred during the daytime of 19 March 2006 and produced catastrophic flash flooding over the highly urbanized area of Dallas County, Texas. A line of LEC convection developed and trained across Dallas County between 1800-2200 UTC. Rain gauges in Dallas reported rainfall rates exceeding $75 \mathrm{~mm} \mathrm{~h}^{-1}\left(3 \mathrm{in} \mathrm{h}^{-1}\right)$ with 3-h totals of 150 $200 \mathrm{~mm}$ (6-8 in) being common. One fatality occurred in downtown Dallas as a result of swift water overtaking a vehicle that was crossing a flooded roadway. Damage for this event was estimated at $\$ 2$ million (NCDC 2006).

\section{2) SOUNDING ANALYSIS}

A 1200 UTC upper-air observation from Fort Worth, Texas [FWD, $45 \mathrm{~km}$ (28 mi) to the west of the flash flood], was unavailable because of equipment failure. A RUC-2 model sounding at 1200 UTC over Dallas was used instead for this analysis and suggests the atmosphere was favorable for the development of LEC convection (Fig. 4). The nearly saturated profile resulted in a PW value near $35 \mathrm{~mm}$ (1.40 in; $250 \%$ of normal). The WCD was large at $5.3 \mathrm{~km}(17400 \mathrm{ft})$. The CAPE from a parcel lifted at $900 \mathrm{hPa}$ was 106 $\mathrm{J} \mathrm{kg}^{-1}$ and had a narrow profile up to the EL at $490 \mathrm{hPa}$ (or $5.7 \mathrm{~km}$ ), where the environmental temperature was only $-14^{\circ} \mathrm{C}$. Shear within the WCD was larger than for the other cases examined. Deep-layer shear values were near $15 \mathrm{~m} \mathrm{~s}^{-1}(30 \mathrm{kt})$, but the wind profile lacked significant directional turning. Since the column was nearly saturated and radar-echo training was parallel to the shear vector, the higher shear may not have been a negating factor in the development of heavy rain and high precipitation efficiency.

\section{3) RADAR/SATELLITE ANALYSIS}

This event presented challenges to the NWS operational warning program as flash flooding and severe convection with large hail occurred simultaneously within the same radar domain. The severe convection developed in a more unstable air mass well

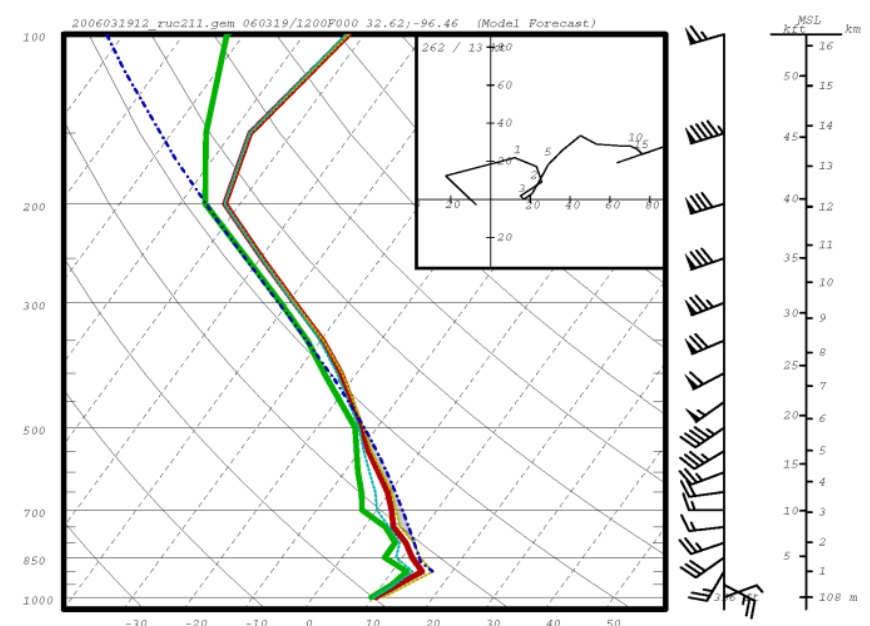

Figure 4. As in Fig. 1 except for 1200 UTC 19 March 2006 for the LEC cell near Dallas, TX.

to the south and east of the area impacted by heavy rain. Radar-based rainfall estimates obtained while operating in the standard convective $Z-R$ mode were reliable in areas where normal continental (or HEC) convection was occurring; however, rainfall estimates were 3-4 times too low in locations where LEC convection was occurring. Even after the radar $Z-R$ algorithm was switched to the Rosenfield tropical at 1900 UTC, rainfall estimation still ranged from 1.5-2 times below actual rain-gauge reports across Dallas County through the end of the event.

The composite reflectivity is the maximum reflectivity scanned by the radar in a vertical column (Klazura and Imy 1993). Composite reflectivity at 2005 UTC (Fig. 5a) shows maximum values between 50-55 dBZ. A cross section along the training line of convection over Dallas County at 2005 UTC confirms the LEC characteristics this convection exhibited for the duration of the flood event (Fig. 5b). Reflectivity values were highest in the lower levels of the convection, with most of the reflectivity that was $>35$ $\mathrm{dBZ}$ confined to below the $-10^{\circ} \mathrm{C}$ level. During the course of the event, the training line of convection never displayed reflectivity values $>57 \mathrm{dBZ}$. VIL generally ranged between $10-20 \mathrm{~kg} \mathrm{~m}^{-2}$, and only twice exceeded $25 \mathrm{~kg} \mathrm{~m}^{-2}$. ETs ranged between $10.7-$ $13.7 \mathrm{~km}$ (35 000-45 $000 \mathrm{ft}$ ) AGL, with VIL density extraordinarily low, generally $1.0-1.5 \mathrm{~kg} \mathrm{~m}^{-3}$.

The LEC convection in this case produced several hundred CG lightning strikes. The satellite presentation also was unlike the first case discussed in that a large shield of very cold cloud tops (colder than $-75^{\circ} \mathrm{C}$ ) developed and expanded during the peak of the 

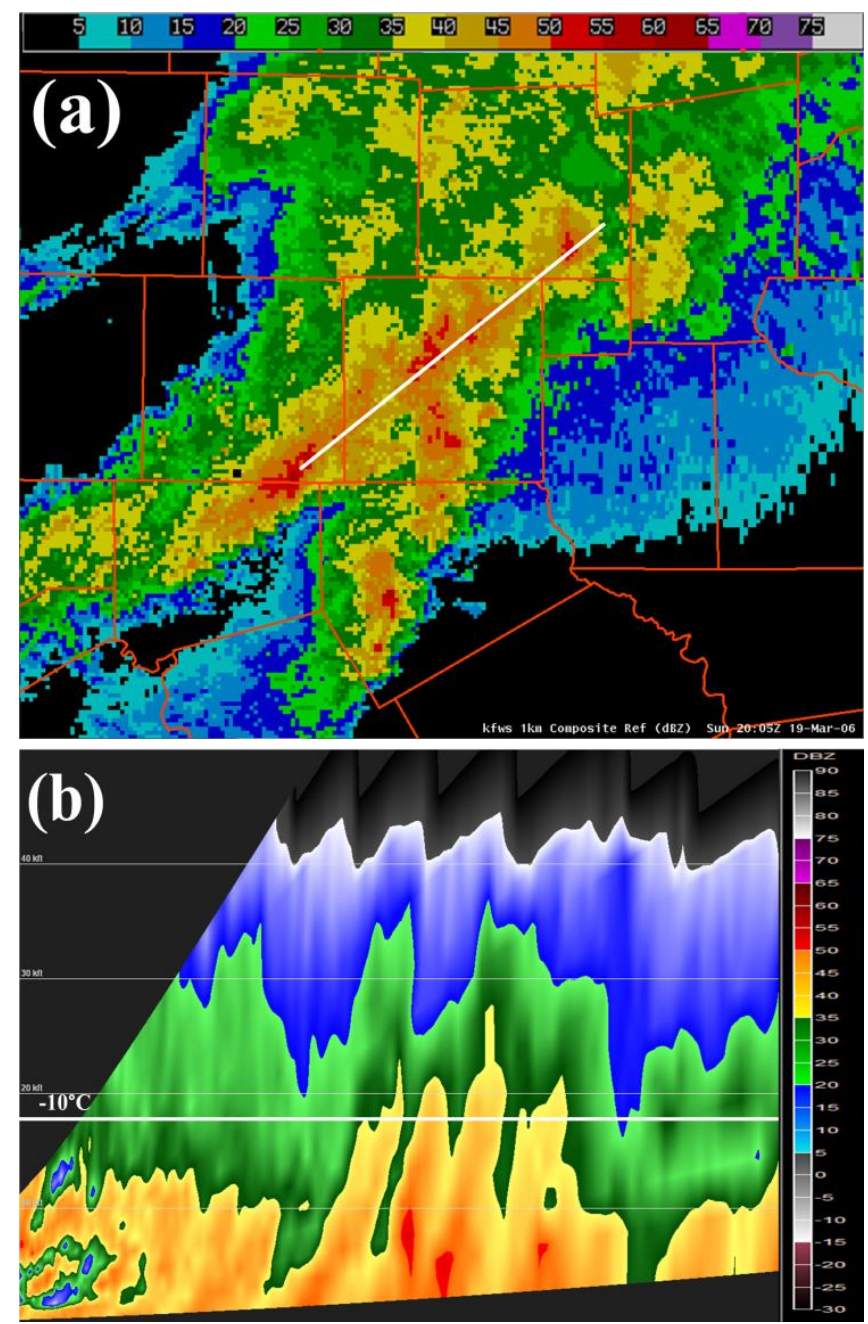

Figure 5. As in Fig. 3 except for Dallas-Fort Worth, TX (KFWS) at 2005 UTC 19 March 2006. The cross section runs southwest-tonortheast.

excessive rainfall event (Fig. 6). The high ETs, satellite presentation, and lightning activity are indicative that the EL and maximum parcel level gained significant altitude during the event. Although numerous CG lightning strikes and cold cloud-top temperatures seem to contradict the existence of an LEC cell, the radar signature clearly showed LEC characteristics. This demonstrates that satellite and CG lightning signatures must be examined in context with other data.

\section{c. Union, Missouri (7 May 2000)}

\section{1) OVERVIEW}

During the overnight hours of 7 May 2000, a mesoscale convective system (MCS) developed over east-central Missouri, just west of the St. Louis metro area. The MCS initiation was due to a mesoscale convective vortex that resulted from thunderstorm development the previous night across Oklahoma. The MCS initially developed around 0200 UTC and lasted until about 1300 UTC. Union, Missouri, received a storm-total rainfall of $350 \mathrm{~mm}$ (14 in) in $6 \mathrm{~h}$ from 0500-1100 UTC. This extreme amount of rainfall led to $\$ 100$ million in damage and two fatalities (NCDC 2000; Glass et al. 2001; Schumacher and Johnson 2008).

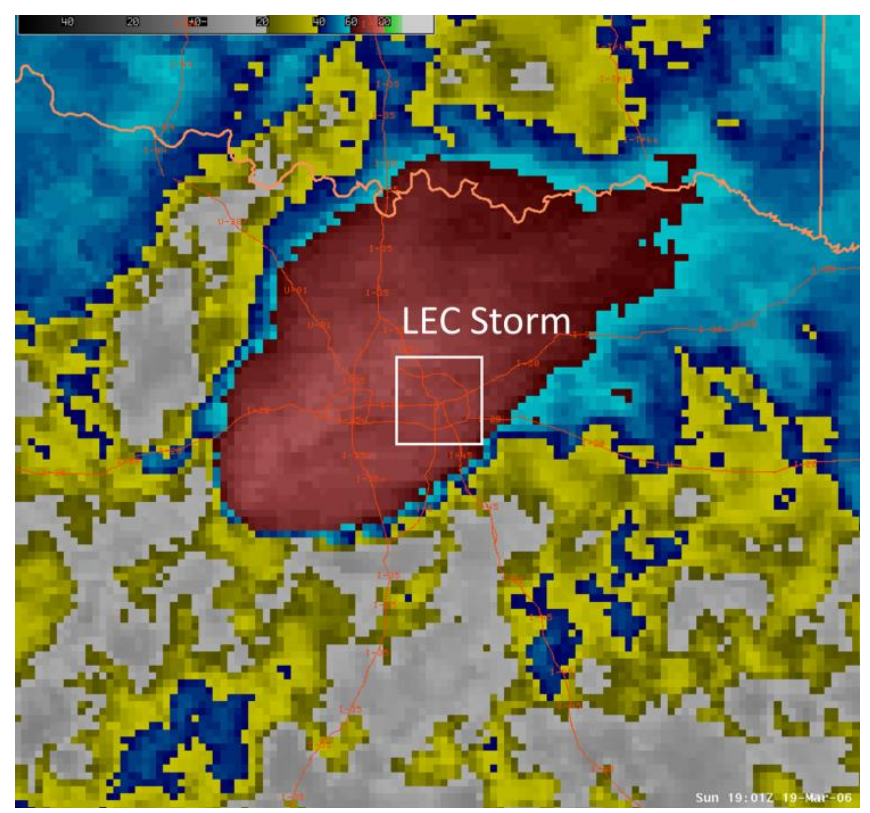

Figure 6. As in Fig. 2 except for 1900 UTC 19 March 2006 in Texas. The location of the LEC storm and Dallas County are outlined in white.

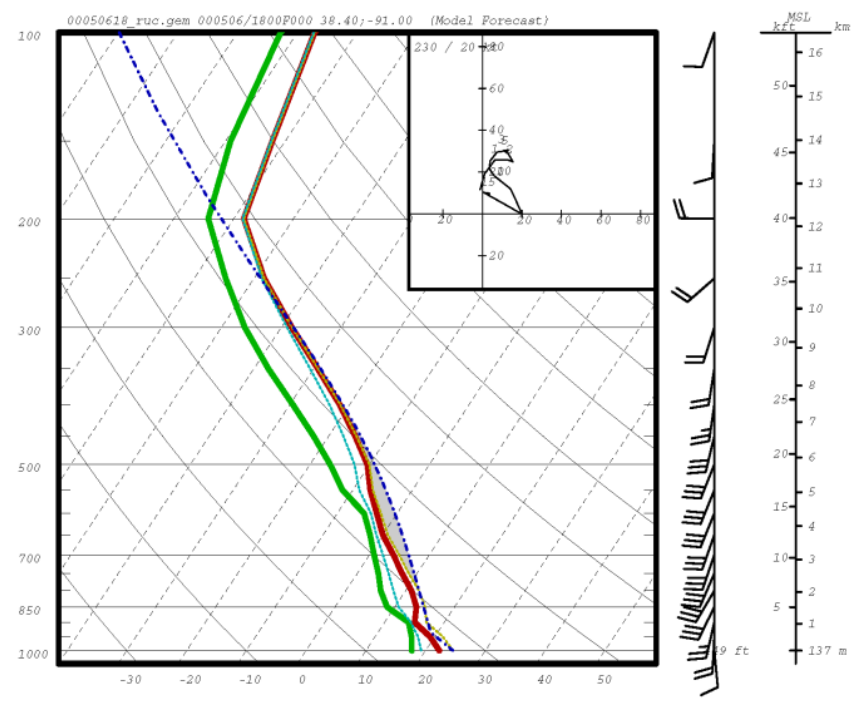

Figure 7. As in Fig. 1 except for 1800 UTC 6 May 2000 for the LEC cell in eastern Missouri. 


\section{2) SOUNDING ANALYSIS}

A RUC-2 sounding at 1800 UTC 6 May 2000 (Fig. 7) was generated at the LEC storm location in eastern Missouri. The CAPE derived from this sounding was $300 \mathrm{~J} \mathrm{~kg}^{-1}$. The EL was at $280 \mathrm{hPa}$ while the tropopause was at $200 \mathrm{hPa}$. The wind profile indicated some veering with height in the positive CAPE area (gray, Fig. 7). However, speed shear within this layer was weak as winds ranged from 5-15 $\mathrm{m} \mathrm{s}^{-1}(10-30 \mathrm{kt})$, with the strongest winds in the lowest levels. The WCD in the model sounding was large and approached $5.9 \mathrm{~km}$ (19 $300 \mathrm{ft}$ ). The cloud-bearing layer of the sounding was nearly saturated and the PW was $38 \mathrm{~mm}$ (1.49 in; $145 \%$ of normal).

\section{3) RADAR/SATELLITE ANALYSIS}

An examination of a GOES-IR enhanced satellite image at 1015 UTC 7 May 2000 (Fig. 8) shows cold cloud tops associated with this event. Observed cloudtop temperatures were between -75 and $-80^{\circ} \mathrm{C}$. The strong cloud-top temperature gradient on the westcentral flank of the MCS was the point of regeneration and location of the highest rainfall totals with this MCS. Additionally, several CG strikes were reported during the peak of the MCS. As with the Dallas case, cold cloud tops and CG lightning strikes were occurring even though there was a clear radar signature of LEC convection.

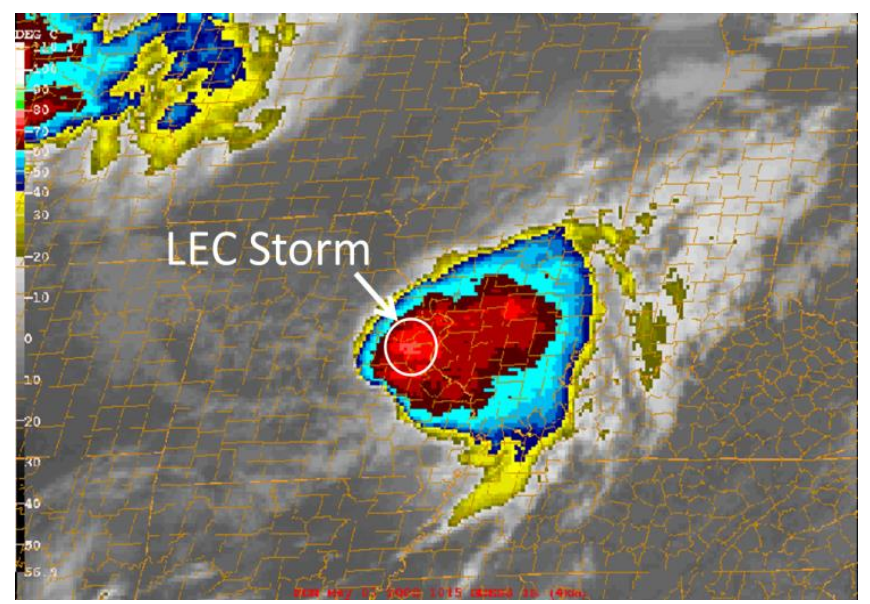

Figure 8. As in Fig. 2 except for 1015 UTC 7 May 2000 in northeastern Missouri. The location of the LEC storm is indicated by the white arrow and circle.

The LEC storm was determined to be deepest around 0635 UTC based on examination of radar cross sections from St. Louis, Missouri (KLSX). Composite reflectivity at 0635 UTC shows maximum values between 55-60 dBZ (Fig. 9a). These reflectivity values remained persistent for many hours during the storm's lifecycle. The corresponding cross section (Fig. 9b) shows the 60-dBZ echo entirely below the $-10^{\circ} \mathrm{C}$ isotherm. Even though this storm was "bottomheavy," reflectivity values up to $35 \mathrm{dBZ}$ extended through a deep layer of the atmosphere-reaching 12.0 km (40 $000 \mathrm{ft})$ AGL. The WSR-88D underestimated rainfall by about $20 \%$ using the standard $Z-R$ relationship. VIL generally ranged between $30-40 \mathrm{~kg}$ $\mathrm{m}^{-2}$. Corresponding ET values at the same time ranged from 13.7-15.2 km (40 000-50 000 ft) AGL, resulting in VIL density values around $2.0 \mathrm{~kg} \mathrm{~m}^{-3}$.

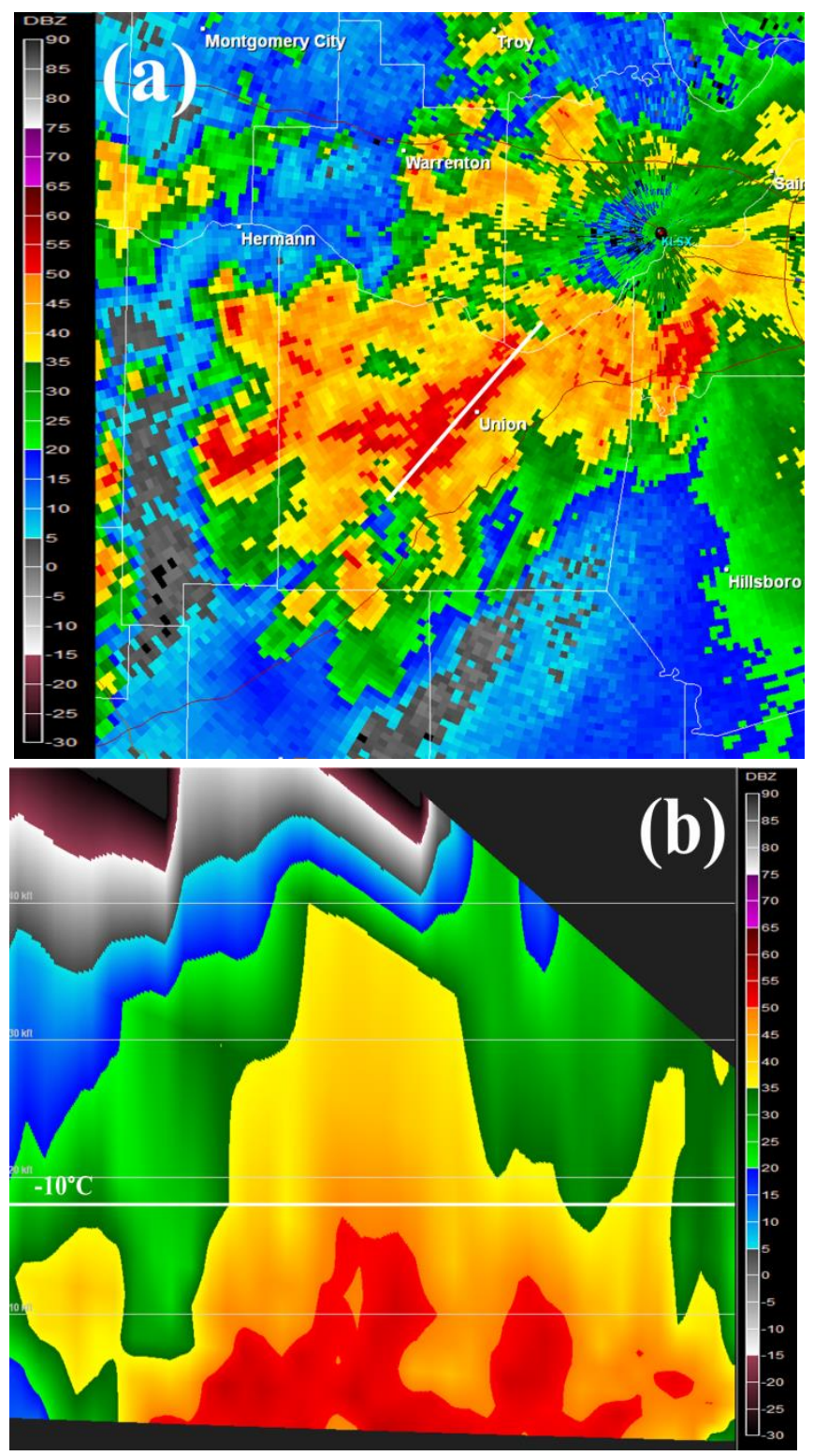

Figure 9. As in Fig. 3 except for KLSX, at 0635 UTC 7 May 2000. The cross section runs southwest-to-northeast. 


\section{d. Lancaster, Texas (28-29 July 2004)}

\section{1) OVERVIEW}

Scattered unorganized convection developed during the late afternoon around 2100 UTC 28 July 2004 with isolated severe-wind and large-hail reports associated with thunderstorms that briefly exhibited supercellular structures. Convection continued to develop into the evening, and the event began to transition to a catastrophic flash-flood episode beginning at 0200 UTC 29 July 2004. The excessive rainfall rates reached their peak between $0400-0700$ UTC and primarily affected the southern Dallas, Texas, suburb of Lancaster, in south-central Dallas County. Several rain gauges recorded over $205 \mathrm{~mm}(8$ in) of rain in $2 \mathrm{~h}$, with overnight rainfall totals in excess of $310 \mathrm{~mm}$ (12 in). Almost \$26 million in damage was incurred, and over 120 high-water rescues were performed. Tragically, three fatalities occurred when vehicles were driven across flooded roadways (NCDC 2004).

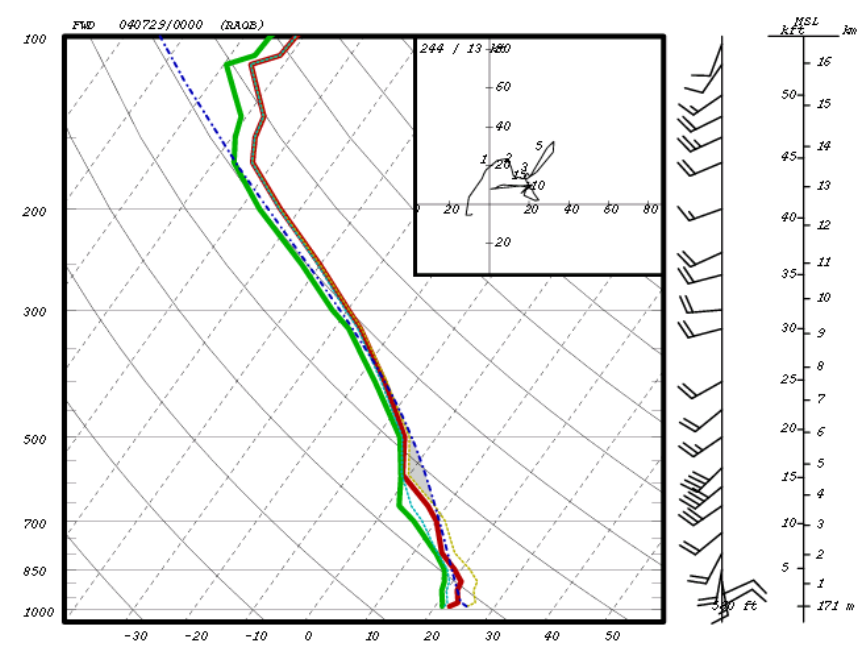

Figure 10. As in Fig. 1 except for the observed FWD sounding at 0000 UTC 29 July 2004 for the LEC cell near Lancaster, TX.

\section{2) SOUNDING ANALYSIS}

The atmosphere over the region during this event contained weak amounts of wind shear and weak-tomoderate amounts of instability. Although CAPE values $>1000 \mathrm{~J} \mathrm{~kg}^{-1}$ were present during the late afternoon hours when severe convection was occurring, the loss of insolation, as well as significant convective overturning, resulted in more limited instability during the evening hours. A sounding at 0000 UTC from FWD, located $55 \mathrm{~km}$ (34 mi) to the northwest of the flash flood, was determined to be representative of the environment in the region (Fig. 10). It shows PW at $57 \mathrm{~mm}$ (2.20 in; $150 \%$ of normal) associated with a nearly saturated air mass. The WCD was very large with a depth over $6.0 \mathrm{~km}(19600 \mathrm{ft})$. A nearly moist adiabatic lapse rate from the surface up to the tropopause resulted in a narrow CAPE profile. While CAPE values from the FWD sounding were only near $130 \mathrm{~J} \mathrm{~kg}^{-1}$, surface temperatures and dewpoints were slightly higher across southern Dallas County, which resulted in estimated CAPE values near $600 \mathrm{~J} \mathrm{~kg}^{-1}$ and an EL near $200 \mathrm{hPa}$ during the peak of the event. Wind speeds through the entire troposphere were all $<20 \mathrm{~m} \mathrm{~s}^{-1}(40 \mathrm{kt})$, and $0-6-\mathrm{km}$ bulk shear was near $13 \mathrm{~m} \mathrm{~s}^{-1}(25 \mathrm{kt})$.

\section{3) RADAR/SATELLITE ANALYSIS}

Accuracy of radar rainfall estimates fluctuated dramatically during the event as convective cells transitioned between HEC and LEC modes. Through the use of a high-density rain-gauge network available from the City of Dallas Flood Control District, the accuracy of radar precipitation estimates were calculated and compared to reflectivity characteristics of convective cells.

Radar-derived rainfall estimates were in reasonably good agreement with rain gauge reports of 25-50 $\mathrm{mm} \mathrm{h}^{-1}\left(1-2\right.$ in $\left.^{-1}\right)$ from 0200-0400 UTC. Figure 11 shows southwest-to-northeast reflectivity cross sections centered over Lancaster in south-central Dallas County from 0340-0510 UTC at 30-min intervals. Figure $11 \mathrm{~b}$ at 0340 UTC indicates an HEC cell over south-central Dallas County. Figures 11c-e show the evolution of the convection from 0410-0510 UTC as it evolved into a steady-state LEC mode. For the 1 -h period ending at 0400 UTC, Fig. 12a indicates rainfall estimates were accurate or slightly overestimated in south-central Dallas County (associated with the HEC cell). After 0400 UTC, convection transitioned to an LEC mode and rainfall rates increased to as high as $100 \mathrm{~mm} \mathrm{~h}^{-1}\left(4 \mathrm{in} \mathrm{h}^{-1}\right)$. Rainfall was significantly underestimated by the radar in some locations by a factor of two or more (Figs. 12b,c). This resulted in as much as $100 \mathrm{~mm}$ (4 in) of rainfall that was not estimated by the radar within a 2-h period, and contributed to a much more serious flash-flooding episode than was anticipated.

Composite reflectivity showed maximum reflectivity values as high as $72 \mathrm{dBZ}$ when $19-\mathrm{mm}(0.75 \mathrm{in})$ diameter hail was occurring, but these values also diminished below $60 \mathrm{dBZ}$ after 0300 UTC. VIL from 


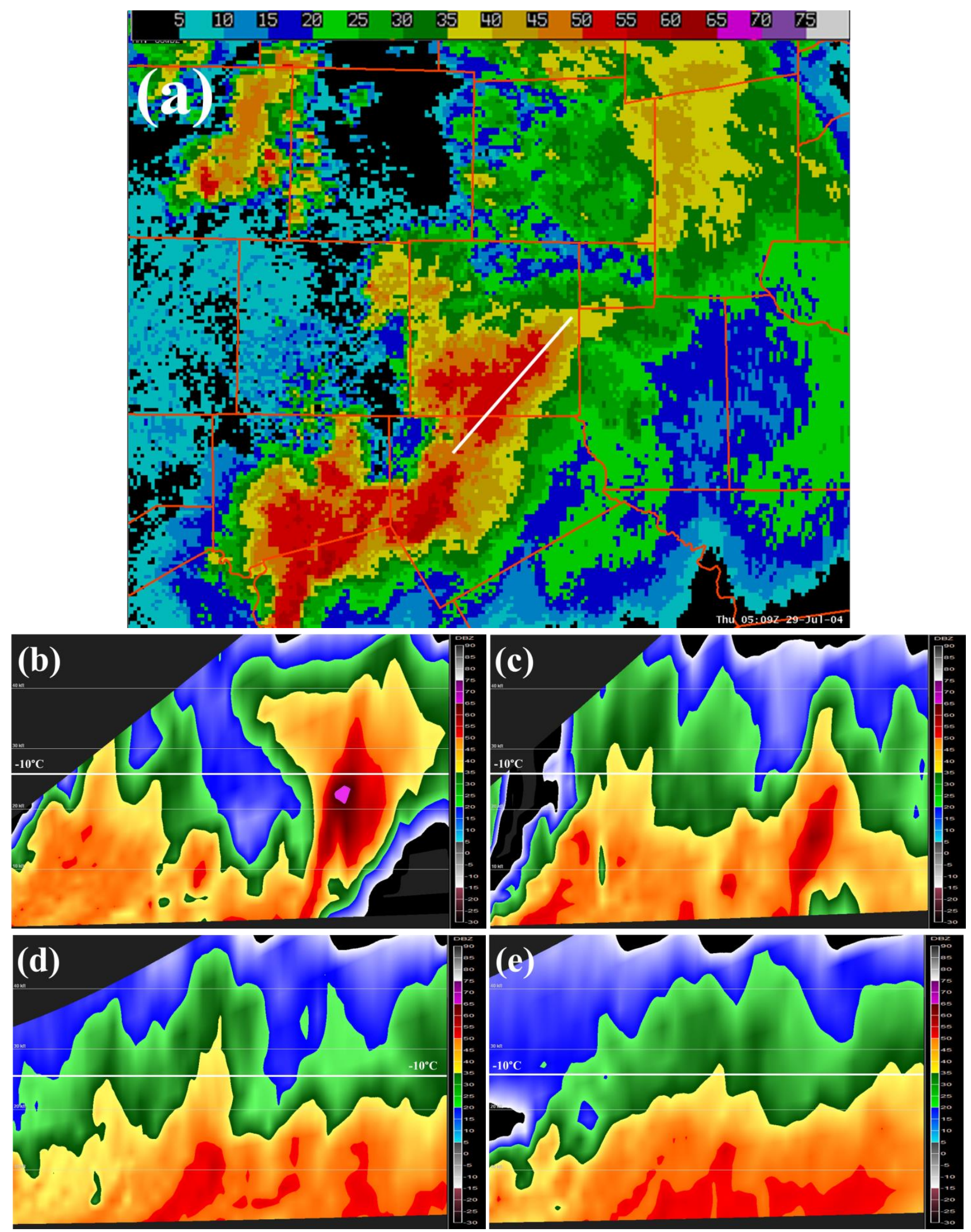

Figure 11. (a) KFWS WSR-88D composite reflectivity at 0509 UTC 29 July 2004. The thick line through the LEC cell indicates the orientation of the cross sections shown in $11 \mathrm{~b}-\mathrm{e}$. KFWS reflectivity cross sections from southwest-to-northeast at (b) 0340 UTC, (c) 0410 UTC, (d) 0440 UTC, and (e) 0510 UTC. The thick horizontal white line indicates the $-10^{\circ} \mathrm{C}$ isotherm. 

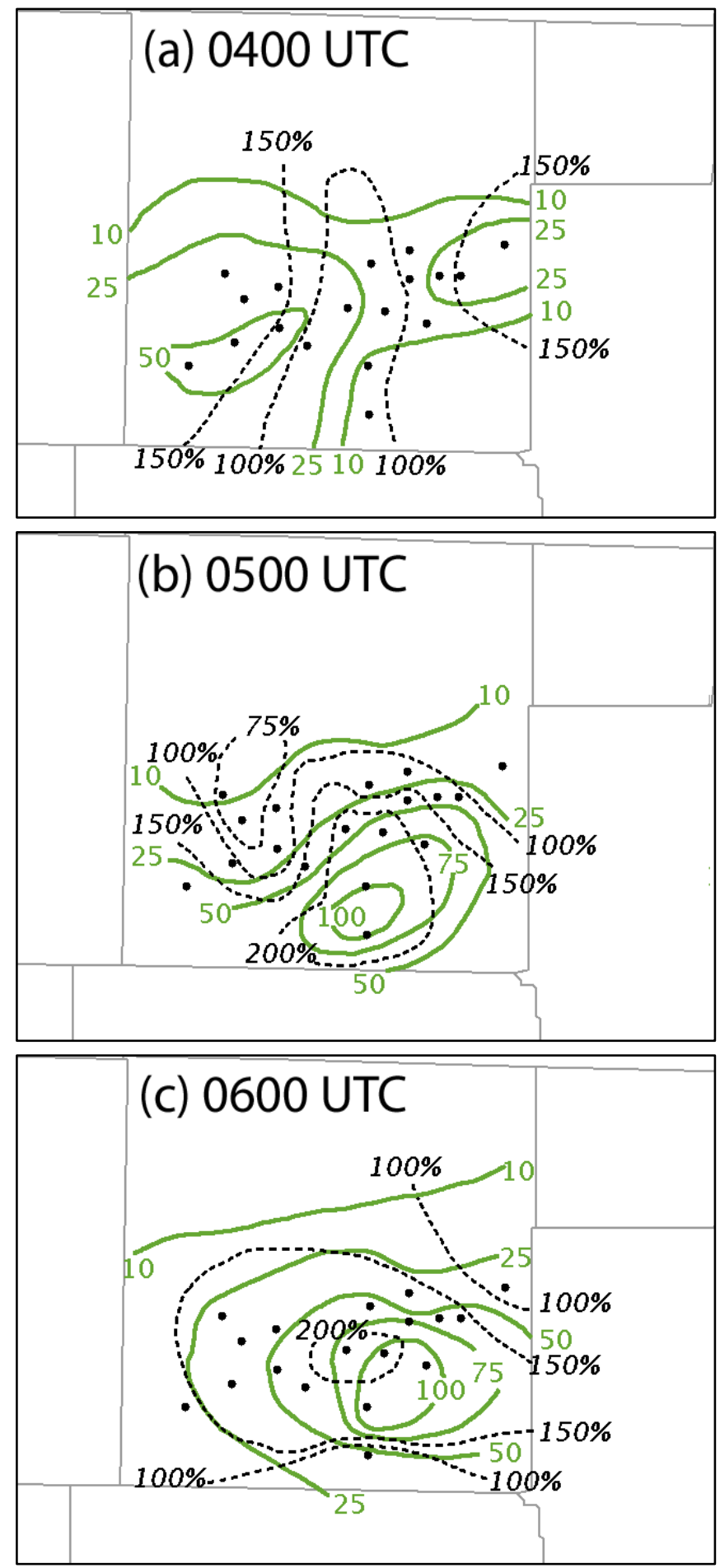

Figure 12. Hand-drawn analyses of 1 -h rainfall and radar rainfall estimation of performance (\%) over Dallas County ending at (a) 0400 UTC, (b) 0500 UTC, and (c) 0600 UTC 29 July 2004. Rainfall contours are shown in the solid green isohyets in $\mathrm{mm}$. The dashed black isopleths are radar rainfall estimates relative to the 1$\mathrm{h}$ analyses; values $>100 \%$ indicate radar underestimation and values $<100 \%$ indicate radar overestimation. The black dots are the locations of the available rain gauges used for the analyses. the radar showed values over Dallas County ranging between 10-30 $\mathrm{kg} \mathrm{m}^{-2}$ from 0400-0700 UTC when the heaviest rain fell. ETs at this time were frequently in excess of $12.0 \mathrm{~km}(40000 \mathrm{ft})$ AGL, which resulted in VIL density readings below $2.0 \mathrm{~kg} \mathrm{~m}^{-3}$.

Numerous CG lightning strikes were detected between 0300-0400 UTC, primarily associated with the HEC high-precipitation supercell as it entered south-central Dallas County. Again, the presence of numerous CG lightning strikes did not mean LEC convection was not occurring. It is interesting to note that the number of CG strikes dramatically diminished as transformation to LEC convection occurred (Fig. 13), and thus lightning-rate trends with specific convective cells may offer a clue that an LEC transformation is occurring. Similar to the previous two cases, GOES-IR satellite depicted an expanding shield of very cold cloud tops after 0300 UTCreaching $-79^{\circ} \mathrm{C}$ (Fig. 14). Despite convection being deep enough to reach the tropopause, it did not mean collision-coalescence processes could not dominate rainfall production.

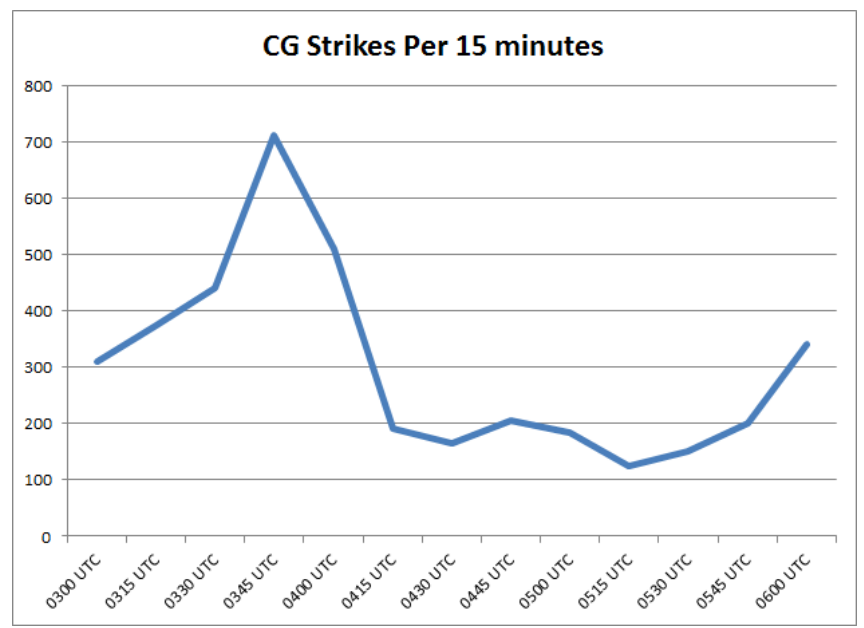

Figure 13. CG lightning strikes per 15-min intervals associated with the Dallas County convection from 0300-0600 UTC 29 July 2004.

\section{Operational identification methods}

The authors propose unique terminology to differentiate the primary physical processes occurring in the first case (Kansas Turnpike) versus the last three (Dallas, Texas; Union, Missouri; Lancaster, Texas). The first case, labeled type A, involved isolated convective cells where collision-coalescence was contributing almost exclusively to precipitation production. The second set, or last three cases, are 


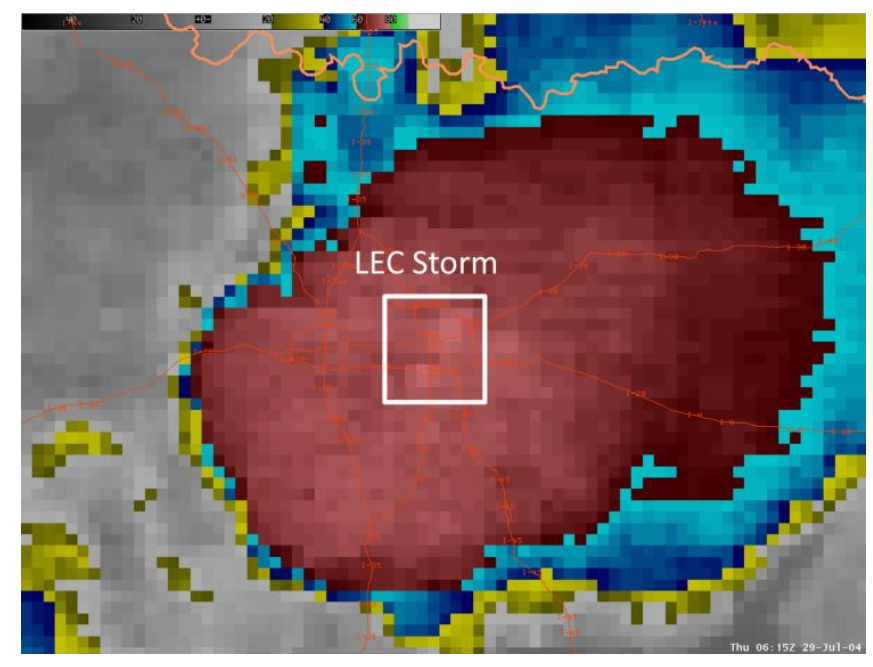

Figure 14. As in Fig. 2 except for 0615 UTC 29 July 2004 in TX. The location of the LEC storm and Dallas County are outlined in white.

referred to as type B events. Collision-coalescence likely dominated the precipitation production, but some elements of deep continental convection also were occurring. Specifically, type B cases (i) did not involve shallow convection, (ii) had stronger updraft velocities, and (iii) were not devoid of quantities of ice within the upper portions of convective cells. Despite this, LEC convection was identified in type B cases. Table 1 provides a brief comparison between the meteorological characteristics of all four cases examined. The values displayed in Table 1 show that each of the cases shared similarities to tropical environments. WSR-88D derived values indicate a unique situation where the warm-rain process was the dominant precipitation-production mechanism.

By expanding on the definition of LEC convection, and recognizing the case of HEC convection, we have created a detailed LEC storm definition and a classification system that will allow for better real-time recognition of type A and B events. The real-time detection of both types of LEC convection will allow operational forecasters to improve on flash-flood warning decisions. A common trait in all of the cases presented is that reflectivity values >60 dBZ were not observed anywhere in the cell, which is the most important addition to the definition of an LEC. This suggests that the ice phase was limited or confined to the upper portions of the cells where it did not contribute or interfere with the collision-coalescence precipitation process. The cell should have increasing reflectivity as height decreases and exhibit no tilt in the vertical structure. Reflectivity
Table 1. A comparison of meteorological characteristics between type A and type B events (see section 4 for a discussion).

\begin{tabular}{|c|c|c|c|c|}
\hline \multirow{2}{*}{$\begin{array}{l}\text { Event } \\
\text { Parameter }\end{array}$} & \multirow{2}{*}{$\begin{array}{c}\text { Type A } \\
\text { Kansas } \\
\text { Turnpike }\end{array}$} & \multicolumn{3}{|c|}{ Type B } \\
\hline & & $\begin{array}{c}\text { Dallas, } \\
\text { Texas }\end{array}$ & $\begin{array}{l}\text { Union, } \\
\text { Missouri }\end{array}$ & $\begin{array}{c}\text { Lancaster, } \\
\text { Texas }\end{array}$ \\
\hline WCD $(\mathrm{km})$ & 6.4 & 5.3 & 5.9 & 6.0 \\
\hline CAPE $\left(\mathrm{J} \mathrm{kg}^{-1}\right)$ & 316 & 106 & 580 & 600 \\
\hline $\begin{array}{l}\text { PW (mm) } \\
\text { (\% of normal) }\end{array}$ & $\begin{array}{c}48 \\
(120 \%)\end{array}$ & $\begin{array}{c}35 \\
(250 \%)\end{array}$ & $\begin{array}{c}38 \\
(145 \%)\end{array}$ & $\begin{array}{c}57 \\
(150 \%)\end{array}$ \\
\hline $\begin{array}{l}\text { Max composite } \\
\text { reflectivity } \\
\text { (dBZ) }\end{array}$ & 55 & 57 & 60 & 60 \\
\hline $\operatorname{VIL}\left(\mathrm{kg} \mathrm{m}^{-2}\right)$ & $25-30$ & $10-20$ & $30-40$ & $10-30$ \\
\hline $\mathrm{ET}(\mathrm{km})$ & $10.7-12.2$ & $10.7-13.7$ & $\begin{array}{c}13.7- \\
15.2\end{array}$ & $13.7-15.2$ \\
\hline $\begin{array}{l}\text { VIL density } \\
\left(\mathrm{kg} \mathrm{m}^{-3}\right)\end{array}$ & $1.5-2.0$ & $1.0-1.5$ & $1.5-2.0$ & $1.5-2.0$ \\
\hline
\end{tabular}

values $<35 \mathrm{dBZ}$ above the $-10^{\circ} \mathrm{C}$ level appear to be inconsequential to warm-cloud precipitation production. In all cases the LEC was identified primarily through the use of a radar cross section. Whereas the cross section is an excellent tool in which to identify a cell with an LEC, it is not feasible to perform cross sections of all convective cells, particularly if a severe weather episode is underway. Cross sections can be utilized as a final test for any suspect LEC cells. Several faster techniques can be utilized in an operational setting for the detection of both types of LEC storms; these may require algorithm development and/or automation to be more practical in real-time.

Using the technique of comparing maximum VIL versus maximum ET for LEC cells resulted in low values of VIL density. All LEC convection in the cases had VILs $<40 \mathrm{~kg} \mathrm{~m}^{-2}$ and ETs $>10.7 \mathrm{~km}$ (35000 ft) AGL, and therefore VIL densities $\leq 2.0 \mathrm{~kg} \mathrm{~m}^{-3}$. VIL density was determined to be an excellent way to eliminate HEC convective cells on a plan view. The 19 March 2006 case was an example where VIL density was very low with LEC convection (sometimes $<1.0$ $\mathrm{kg} \mathrm{m}^{-3}$ ), while severe convection simultaneously had very large values $>4.0 \mathrm{~kg} \mathrm{~m}^{-3}$. Even if HEC cells grow to $18.3 \mathrm{~km}(60000 \mathrm{ft})$ AGL and have a VIL greater than $40 \mathrm{~kg} \mathrm{~m}^{-2}$, they would have a VIL density higher than the $2.0 \mathrm{~kg} \mathrm{~m}^{-3}$ threshold. Therefore, a VIL $>40$ $\mathrm{kg} \mathrm{m}^{-2}$ would almost always be associated with HEC convection.

LEC cells with excessive rain rates displayed a steady-state maximum reflectivity between $45-55 \mathrm{dBZ}$ on the composite reflectivity owing to the fact that updrafts are less intense in LEC cells than in HEC 
cells - thus the LEC cells lack significant ice-phase hydrometeors. Forecasters should be alert for cells that display a life cycle of maximum reflectivity values within this range. It is a signal that the mean drop-size diameter in the DSD may have reached its theoretical collision-coalescence maximum centered at 2-3 mm and rainfall may be severely underestimated by normal convective $Z-R$ relationships. However, cells containing reflectivity $>60 \mathrm{dBZ}$ may have large areas of reflectivity from $45-55 \mathrm{dBZ}$ too, but the presence of large-diameter hydrometeors suggests the DSD is characterized by a small amount of large-diameter hydrometeors not produced by collision-coalescence. Using composite reflectivity to find indications of reflectivity $>60 \mathrm{dBZ}$ within a cell over a large area or for a long duration will allow the forecaster to discard consideration of convection with too much ice infused into the precipitation-production process.

If the maximum value of composite reflectivity is identical to that of the base reflectivity, it suggests a "bottom-heavy" structure with no tilted structure in the vertical. In the cases examined, cells that had reflectivity $>60 \mathrm{dBZ}$ produced high rainfall rates, but those rates were adequately estimated by standard convective $Z-R$ relationships. It should be noted that cells with maximum reflectivities $\angle 45 \mathrm{dBZ}$ may be indicative of warm-rain processes and convective $Z-R$ underestimation but are not likely to produce excessive rainfall rates that would lead to flash flooding. In areas with minimal beam blocking, identical-looking composite reflectivity and base (or $0.5^{\circ}$ ) reflectivity products also were an easy way to find LEC cells, especially among several convective cells occurring simultaneously. Table 2 provides a summary of these radar-derived parameters.

CG lightning strikes can occur with LEC convection, especially in the type B cases. Lightning strikes should be few in number compared to any surrounding HEC convection with a deep convective signature. Because lightning discharges occurred, a combination of graupel and strong updraft velocities had been present in the upper portions of the LEC cells. The presence of CG lightning strikes and cold cloud tops does not necessarily rule out the presence of LEC convection (i.e., where the collision-coalescence process is dominating precipitation production).

\section{Conclusion}

Four excessive rainfall events in the south-central United States were studied in order to identify
Table 2. LEC cell identification criterion.

\begin{tabular}{|l|l|}
\hline Parameter & Value \\
\hline VIL $\left(\mathrm{kg} \mathrm{m}^{-2}\right)$ & $\leq 40$ \\
\hline ET $(\mathrm{km} \mathrm{AGL})^{\text {VIL density }\left(\mathrm{kg} \mathrm{m}^{-3}\right)}$ & $\geq 10.7$ \\
\hline Reflectivity $(\mathrm{dBZ})$ & $\leq 2.0$ \\
\hline
\end{tabular}

common traits and characteristics of LEC convective events where collision-coalescence is the primary precipitation-production mechanism. Several atmospheric parameters must be favorable for this type of precipitation process to organize. Yet, in many cases, the real-time radar, satellite, and lightning data must be analyzed for each cell to determine whether collision-coalescence processes are dominating the rainfall production. The case studies herein showed that a cell's updraft characteristics can change the mechanism that produces the precipitation. Forecasters must be able to quickly identify LEC convection with real-time data sources in order to make accurate and timely warning decisions.

A more detailed and rigorous LEC definition (Table 2) has been put forth to make recognition of the signature more robust for both the type A and the type $\mathrm{B}$ cases. Additional limitations on maximum reflectivity were added to the definition, and it was shown that weak reflectivity values in sub-freezing parts of the convection can be overlooked. VIL density, sideby-side comparison of composite- and base-reflectivity products, and reflectivity cross sections should be used to more easily identify LEC storms in real-time. It is hoped that this research will make recognition of convection with LEC signatures easier, thereby reducing the potential for unwarned flash-flood events.

The WSR-88D network has been upgraded to utilize dual-polarization signals in order to improve the accuracy of areal precipitation estimation. The most significant improvement in areal rainfall estimation is with heavy precipitation that is often mixed with hail (Ryzhkov et al. 2005). In addition to several new quantitative precipitation-estimation products, algorithms utilizing dual-polarization radar data will make a reasonable classification of hydrometeor type (Cifelli et al. 2011). Of particular relevance to this research is quantitative rainfall estimation that will use differential reflectivity to estimate the mean DSD. Although algorithms using dual-polarization radar data should outperform the older generation of algorithms, there are still major limitations in radar sampling that will produce errors, especially at distances beyond $100 \mathrm{~km}$ 
from the radar site. Spreading of the radar beam and a lack of radar sampling in the lowest portions of LEC convective cells still will result in significant rainfall underestimation. Thus, it is imperative that a forecaster recognize the atmospheric potential for, and make a manual classification of, LEC convection for adequate warning decisions. It is not known whether these rare but extreme precipitation events will be captured adequately by dual-polarization WSR-88Ds until operational verification and subsequent research of these events can be performed.

Acknowledgements. The authors thank Dr. Charles Graves of Saint Louis University (Department of Earth and Atmospheric Sciences) for providing additional images. We also thank Steve Cobb (Science and Operations Officer) of the NWS Forecast Office in Lubbock, Texas; Greg Patrick (Science and Operations Officer) of the NWS Forecast Office in Fort Worth, Texas; and Dr. Eric Bruning of the Texas Tech University Geosciences Department for their technical edits and suggestions.

\section{REFERENCES}

Baeck, M. L., and J. A. Smith, 1998: Rainfall estimation by the WSR-88D for heavy rainfall events. Wea. Forecasting, 13, 416-436.

Battan. J. J., and R. R. Braham, 1956: A study of convective precipitation based on cloud and radar observations. $J$. Meteor., 13, 587-591.

Benjamin, S. G., J. M. Brown, K. J. Brundage, B. E. Schwartz, T. G. Smirnova, and T. L. Smith, 1998: The operational RUC-2. Preprints, 16th Conf. on Weather Analysis and Forecasting, Phoenix, AZ, Amer. Meteor. Soc., 249-252.

Brandes, E. A., G. Zhang, and J. Sun, 2006: On the influence of assumed drop size distribution form on radar-retrieved thunderstorm microphysics. J. Appl. Meteor. Climatol., 45, 259-268.

Bringi, V. N., V. Chandrasekar, J. Hubbert, E. Gorgucci, W. L. Randeu, and M. Schoenhuber, 2003: Raindrop size distribution in different climatic regimes from disdrometer and dual-polarized radar analysis. J. Atmos. Sci., 60, 354-365.

Bruning, E. C., W. D. Rust, T. J. Schuur, D. R. MacGorman, P. R. Krehbiel, and W. Rison, 2007: Electrical and polarimetric radar observations of a multicell storm in TELEX. Mon. Wea. Rev., 135, 25252544.

Caracena, F., R. A. Maddox, L. R. Hoxit, and C. F. Chappell, 1979: Mesoanalysis of the Big Thompson storm. Mon. Wea. Rev., 107, 1-17.
Cifelli, R, V. Chandrasekar, S. Lim, P. C. Kennedy, Y. Wang, and S. A. Rutledge, 2011: A new dualpolarization radar rainfall algorithm: Application in Colorado precipitation events. J. Atmos. Oceanic Technol., 28, 352-364.

Davis, R. S., 2001: Flash flood forecast and detection methods. Severe Convective Storms, Meteor. Monogr., No. 50, Amer. Meteor. Soc., 481-525.

, 2004: The impact of tropical rainfall rates on flash flood detection. Preprints, 22nd Conf. on Severe Local Storms, Hyannis, MA, Amer. Meteor. Soc., 11B.5. [Available online at ams.confex.com/ams/pdfpapers/ 81521.pdf.]

Doswell, C. A., III, H. E. Brooks, and R. A. Maddox, 1996: Flash flood forecasting: An ingredients based methodology. Wea. Forecasting, 11, 560-581.

Doviak, R. J. and D. S. Zrnić, 1993: Doppler Radar and Weather Observations. Dover Publications, 562 pp.

Glass, F. H., J. P. Gagan, and J. T. Moore, 2001: The extreme east-central Missouri flash flood of 6-7 May 2000. Preprints, Precipitation Extremes: Prediction, Impacts, and Responses, Albuquerque, NM, Amer. Meteor. Soc., P2.22. [Available online at www.crh.noaa.gov/lsx/?n=franklin_county_flash_flood.]

Kelsch, M., 1998: The Fort Collins flash flood: Exceptional rainfall and urban runoff. Preprints, 19th Conf. on Severe Local Storms, Minneapolis, MN, Amer. Meteor. Soc., 404-407.

Klazura, G. E., and D. A. Imy, 1993: A description of the initial set of analysis products available from the NEXRAD WSR-88D system. Bull. Amer. Meteor. Soc., 74, 1293-1311.

Lamb, D., 2001: Rain production in convective storms. Severe Convective Storms, Meteor. Monogr., No. 50, Amer. Meteor. Soc., 299-321.

Löffler-Mang, M., and J. Joss, 2000: An optical disdrometer for measuring size and velocity of hydrometeors. $J$. Atmos. Oceanic Technol., 17, 130-139.

Lucas, C., E. J. Zipser, and M. A. LeMone, 1994: Vertical velocity in oceanic convection off tropical Australia. $J$. Atmos. Sci., 51, 3183-3193.

Marshall, J. S., and W. Mc. K. Palmer, 1948: The distribution of raindrops with size. J. Meteor., 5, 165166.

NCDC, 2000: Storm Data. 2000 Annual Summaries, National Climatic Data Center, Asheville, NC, 36 pp. [Available online at www.ncdc.noaa.gov/IPS/sd/sd.html.] , 2003: Storm Data. 2003 Annual Summaries, National Climatic Data Center, Asheville, NC, 34 pp. [Available online at www.ncdc.noaa.gov/IPS/sd/sd.html.] , 2004: Storm Data. 2004 Annual Summaries, National Climatic Data Center, Asheville, NC, 36 pp. [Available online at www.ncdc.noaa.gov/IPS/sd/sd.html.]

, 2006: Storm Data. 2006 Annual Summaries, National Climatic Data Center, Asheville, NC, 36 pp. [Available online at www.ncdc.noaa.gov/IPS/sd/sd.html.] 
NOAA, cited 2010: Natural Hazard Statistics. National Weather Service, Silver Spring, MD [Available online at www.nws.noaa.gov/om/hazstats.shtml]. , cited 2011: GPRA Metrics Status Report. [Available online at verification.nws.noaa.gov/services/gpra/index. aspx].

Petersen, W. A., and Coauthors, 1999: Mesoscale and radar observations of the Fort Collins flash flood of 28 July 1997. Bull. Amer. Meteor. Soc., 80, 191-216.

Polger, P. D., B. S. Goldsmith, R. C. Przywarty, and J. R. Bocchieri, 1994: National Weather Service warning performance based on the WSR-88D. Bull. Amer. Meteor. Soc., 75, 203-214.

Rosenfield, D., D. B. Wolff, and D. Atlas, 1993: General probability-matched relations between radar reflectivity and rain rate. J. Appl. Meteor., 32, 50-72.

Ryzhkov, A. V., S. E. Giangrande, and T. J. Schuur, 2005: Rainfall estimation with a polarimetric prototype of WSR-88D. J. Appl. Meteor., 44, 502-515.

Schoenberg Ferrier, B., J. Simpson, and W.-K. Tao, 1996: Factors responsible for precipitation efficiencies in midlatitude and tropical squall simulations. Mon. Wea. Rev., 124, 2100-2125.

Schumacher, R. S., and R. H. Johnson, 2008: Mesoscale processes contributing to extreme rainfall in a midlatitude warm-season flash flood. Mon. Wea. Rev., 136, 3964-3986.

Smith, J. A., M. L. Baeck, M. Steiner, and A. J. Miller, 1996: Catastrophic rainfall from an upslope thunderstorm in the central Appalachians: The Rapidan storm of June 27, 1995. Water Resour. Res., 32, 30993113.

Squires, P., 1956: The microstructure of cumuli in maritime and continental air. Tellus, 8, 443-444.

Srivastava, R. C., 1971: Size distribution of raindrops generated by their breakup and coalescence. J. Atmos. Sci., 28, 410-415.
Ulbrich, C. W., and D. Atlas, 2008: Radar measurement of rainfall with and without polarimetry. J. Appl. Meteor. Climatol., 47, 1929-1939.

Vitale, J. D., J. T. Moore, C. E. Graves, and M. Kelsch, 2009: Hydrometeorological aspects of the Kansas Turnpike flash flood of 30-31 August 2003. Natl. Wea. Dig., 33, 203-218.

Wallace, J. M., and P. V. Hobbs, 1977: Atmospheric Science: An Introductory Survey. Academic Press, 467 pp.

WDTB, cited 2011: Introduction to the Top-Down Methodology, Topic 6, Lesson 1, AWOC Winter Weather Track. Warning Decision Training Branch, Norman, OK. [Available online at www.wdtb.noaa.gov /courses/winterawoc/IC6/lesson1/player.html.] , cited 2012: Distance Learning Operations Course, Topic 5: Base and Derived Products. Warning Decision Training Branch, Norman, OK, 358 pp. [Available online at wdtb.noaa.gov/courses/dloc/outline.html.]

Wilson, J. W., and E. A. Brandes, 1979: Radar measurement of rainfall-A summary. Bull. Amer. Meteor. Soc., 60, 1048-1058.

Yuter, S. E., and R. A. Houze Jr., 1997: Measurements of raindrop size distributions over the Pacific warm pool and implications for $Z-R$ relations. J. Appl. Meteor., 36, 847-867.

Zipser, E. J., and M. A. LeMone. 1980. Cumulonimbus vertical velocity events in GATE. Part II: Synthesis and model core structure. J. Atmos. Sci., 37, 2458-2469.

, and K. R. Lutz, 1994: The vertical profile of radar reflectivity of convective cells: A strong indicator of storm intensity and lightning probability? Mon. Wea. Rev., 122, 1751-1759. 